\title{
The new Adoption Law: Legal and psychological aspects
}

\section{A nova Lei da Adoção: aspectos jurídicos e psicológicos}

\author{
Débora Silva de OLIVEIRA' \\ Eda Regina Doederlein SCHWARTZ
}

\begin{abstract}
From a legal and psychological standpoint, this article examines some aspects involved in adoption, including the effects of the alterations made to the Statute of Children and Adolescents by the National Adoption Law. It verifies whether or not the Law accelerated the performance of adoption processes. This paper is based on bibliographic searches and statistics from Rio Grande do Sul. Results show that the Law was innovative in many aspects but ceased to tackle others, such as adoption by homosexuals. Proceedings have become more bureaucratic, and the number of adoptions in the state, according to the records, remains insignificant. The New Law has not yet achieved its objective of accelerating the adoption process. Institutional sheltering, which should be temporary, at times becomes permanent, which contradicts the right of children/adolescents to family life and results in significant psychological damage to them.
\end{abstract}

Uniterms: Adoption; Legal processes; Psychological aspects; Statute of Children and Adolescents.

\section{Resumo}

A partir do ponto de vista jurídico e psicológico, examinaram-se alguns aspectos envolvidos na adoção, incluindo os reflexos das alterações trazidas ao Estatuto da Criança e do Adolescente pela Lei Nacional da Adoção. Procurou-se verificar se a lei propiciou, ou não, maior celeridade à concretização dos processos. O artigo baseou-se em pesquisas bibliográficas e dados estatísticos do Rio Grande do Sul, Brasil. Os resultados revelaram que a lei inovou em muitos aspectos, mas não abarcou outros, como permitir a adoção por homossexuais. O procedimento se tornou mais burocrático e as adoções por cadastro, no Estado, continuam pouco expressivas. A nova lei ainda não atingiu seu objetivo, o de tornar mais ágeis os processos de adoção. O acolhimento institucional, que deveria ser provisório, torna-se, por vezes, permanente, indo de encontro ao direito à convivência familiar das crianças/adolescentes, causando- Ihes relevantes danos psicológicos.

Unitermos: Adoção; Processos legais; Aspectos psicológicos; Estatuto da criança e do adolescente.

The constantly changing Brazilian society lacks a professional practice permeated by a humanistic, critical, technical and legal vision able to understand the legal phenomenon in an interdisciplinary way. Among the different sciences, psychology practices have constituted an area of productive dialogue in the field of justice, contributing to the production of guarantees of fundamental human rights. Given the above, it is believed that the interface between Psychology and Law can contribute to the understanding of issues involving the adoption of children/adolescents in situations of abandonment.

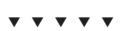

1 Fundação Escola Superior do Ministério Público do Rio Grande do Sul, Faculdade de Direito. R. Cel Genuíno, 421, 6 andar, 90010-350. Porto Alegre, RS, Brasil. Correspondência para/Correspondence to: D.S. OLIVEIRA. E-mail: <debora_deoli@yahoo.com.br>. 
In view of the complexity and particularities of the adoption process, legislators and other professionals involved with this issue constantly seek to evaluate the legislation on adoption. As a result of these evaluations, Law no 12.010/2009 (Brasil, 2009) was enacted, entitled the National Adoption Law. This law revoked the articles of the Brazilian Civil Code dealing with adoption, with the exception of Articles 1618 and 1619, which were amended (Brasil, 2002). It has brought many changes to the Estatuto da Criança e do Adolescente (ECA, Statute of Children and Adolescents) (Brasil, 1990), with respect to the legal provisions dealing with adoption, seeking to accelerate the progress of cases (Dias, 2009a; Medeiros, 2010). The legislative innovations created aimed for the incorporation of mechanisms able to ensure the implementation of the Statute of Children and Adolescents, especially regarding protective measures and the quest for the right to family and community coexistence (Rossato \& Lépore, 2009).

Given the relevance of the topic and based on a review of doctrine on the subject, this article primarily discusses the psychological and legal aspects involved in the adoption process. The main changes introduced by the National Adoption Law, their positive and negative aspects, as well as statistics on adoptions in the state of Rio Grande do Sul in the period 2009-2011 are also covered. Finally, some considerations are presented regarding the changes to the Statute of Children and Adolescents due to the new legislation and comments on whether it has been able to achieve its purpose: that is to streamline the adoption process of children/adolescents.

\section{Psychological and legal aspects involved in the adoption process}

Much of the history of adopted children/ adolescents is permeated by feelings of abandonment, separation and/or interruption of any emotional bond (Paiva, 2004). Statistics of the Court of Appeals of the State of Rio Grande do Sul (Tribunal de Justiça do Rio Grande do Sul, 2011) show that children/adolescents are separated from their families primarily due to abandonment, abuse, family disintegration, illness of parents and issues regarding the economic situation of 446 the family. It can be seen that families are not always able to care for their children (Azambuja, 2002). The removal of the child/adolescent from their family context can lead to psychological consequences, such as the pain of not being accepted by their biological family (Oliveira, 2007). Thus, the decision for this separation is the major responsibility of the professional applying the measure. It is for the Courts and the professionals responsible to seek their reintegration, whether into their own family or into a substitute family, as rapidly as possible.

The Statute of Children and Adolescents prioritizes family reintegration. Whenever possible, emotional bonds with the family of origin should be addressed, prior to the decision for the placement of the child/adolescent in a substitute family. However, during the period in which attempts are made to verify whether the biological family is able to receive the child/adolescent back, or whether the child/adolescent will be sent to a foster home, a sheltering institution will be their new home.

Once institutionalized, children/adolescents grow with an identity of being orphaned or abandoned. They have difficulties in being recognized as individuals belonging to someone or somewhere. Research shows that a prolonged period of institutionalization interferes in the sociability of children/adolescents and in the maintenance of emotional bonds in adulthood. Due to these aspects, there should be no delay in the solution of the problem for the child/adolescent. Furthermore, there are cases where the process to decide whether they can return to their families of origin or whether they should be adopted has not been initiated (Filhos do Coração, 2008; Silva, 2004; Siqueira \& Dell'aglio, 2006).

The effort to seek a place for the child/adolescent within their family of origin should not violate their right to be protected. Some judges cling to formalism, afraid of violating the rights of parents, and forget the rights of the children/adolescents. Many families would require a great deal of time to reorganize, in contrast to the rapid biopsychosocial growth of the child (Silva, 2003). During the time taken by the Judiciary and other professionals involved in the case to see whether the family of origin is able to keep the child/adolescent, they are denied the right to a family, they grow up and then adoption becomes even more difficult. Survey data show that there is still a preference for the adoption of 
white children under two years of age (Azambuja, 2002; Capemisa, 2010; Noal \& Neiva-Silva, 2007). In this context, the need to reduce the length of stay of children/adolescents in sheltering institutions, and to place them in a healthy environment, without violence and drugs, is emphasized, in order for them to have a family and develop more confidently.

Having exhausted the possibilities of the child remaining with his/her biological parents, the focus of the work should be directed toward constructing emotional bonds and trust with the new family. In this transition period with the adoptive family, the child/ adolescent is in a situation of fragility and vulnerability. In addition, children/adolescents show feelings such as rejection, insecurity, low self-esteem and fear of new abandonment (Oliveira, 2007).

From a legal standpoint, the ECA provides for the imposition of protective measures, determined by a competent judicial authority, where the rights of children/adolescents are threatened or violated (Article 98 to 101). These measures can be either administrative (such as guidance, support and temporary monitoring, and inclusion in a community or official aid program) or judicial. Among these measures, there is the method of institutional or family acceptance, or placement in a substitute family.

The institutional acceptance measure is characterized as temporary and transient, until their family reintegration or placement in a substitute family, and does not involve deprivation of freedom. Previously called shelters, the sheltering institutions become the new housing space for children/adolescents, while their return to their families is arranged or they are placed with a substitute family (Rossato \& Lépore, 2009; Silva, 2006). The sheltering institutions develop important work with children/adolescents, given that they provide not only institutional shelter, but also social, educational and protective programs, social and family support, placement in substitute families, and encouragement to have contact with their families (Article 90 of the ECA). They cater for the 0-18 year age group, they usually have the capacity to care for an average of 25 children/ adolescents, and they have an interdisciplinary work team, including educators, social workers, psychologists, and others (Silva, 2006).
In the foster care program, called "Foster Families", the child/adolescent is under the care of a previously registered family. This type of care also consists of a protective provisional measure, applicable only by the Childhood and Youth Circuit Court, following the same rules as for institution care (Rossato \& Lépore, 2009). The "foster family" has temporary custody of the child/adolescent and should create an environment as close as possible to that of a family, until the child's reintegration into the natural family or placement in a substitute family.

Once the impossibility of staying with the biological family is confirmed, the need to place the child/adolescent in a family able to accept them into the home emerges (Azambuja, 2002). Custody and guardianship are similar forms of placement in a substitute family, as they are protective measures that require judicial authorization. However, for guardianship, it is essential to have the dismissal of the family power, a requirement that is not necessary for the granting of custody (Rossato \& Lépore, 2009). Guardianship occurs when there is a suspension or loss of parental authority over the child/adolescent, or when the parents are declared missing. Thus, a guardian is appointed to represent them, to be responsible for them and to manage their assets (Dias, 2009b). On the other hand, custody can be granted to a family caring for a child/ adolescent who lives together with them, but who is not their biological child, and who wants to legally rectify this situation. The custody may be granted preliminarily or temporarily, which is the same for the guardianship and adoption procedures, with the exception of adoption by foreigners (Article 33, §1, of the ECA). Those responsible for custody now have the obligation to provide material, moral and educational assistance to the child/adolescent, and the right to object to third parties, including the biological parents (Rossato \& Lépore, 2009). This institute does not prevent the exercise of visitation rights by biological parents and does not remove their obligation to pay child support.

Another form of placement in a substitute family consists of adoption, which is the focus of this article. Adoption is an act in which a person (or a couple) takes another child in order to support them and offer them a good family environment for their development (Granato, 2010). It is characterized as a complex 
procedure with many particularities, as it is not simply a way to restore families, but a voluntary act of love (Caíno, 2007; Oliveira, 2007).

According to the Statute of Children and Adolescents (Article 39, § 1), adoption is an exceptional measure, which should only be used when all possible resources to keep the child/adolescent within their natural or extended family are exhausted. This protective measure extinguishes the kinship relationship with the natural family and establishes a new kinship between the adoptee and the substitute family. Thus, the adopted children become the actual children of the adopter(s), with the same rights and duties as biological children, including inheritance and the use of the last name of the parents (Granato, 2010). Adoption takes effect only after there is no further possibility of appealing the decision, however, it will only be granted if there are real advantages to the adoptee and if based on legitimate reasons (Caíno, 2007; Rossato \& Lépore, 2009). Adoption is irrevocable.

The meaning of adoption, the motivation, the expectations of the applicants, and the real advantages for the adoptee should be investigated by the Judiciary interprofessional team (comprised of psychologists, social workers, etc.), responsible for the selection of applicants to become adoptive parents (Oliveira, 2007; Azambuja, 2002). The psychosocial study optimizes conditions for successful adoption, as it can prevent possible dysfunctions (Campos \& Costa, 2003, 2004; Weber, 2005), and avoid the risk of exposing adoptees to other traumatic situations of abandonment (Azambuja, 2002). This study should also contain psychosocial support to assess the ability and preparation of adopters to pursue responsible parenthood, according to the requirements and the guiding principles of the ECA (Article 197-C, head provision).

In a context of arrival of new members, the entire adopting family should be prepared and monitored during the parental transitional period (Oliveira, 2007; Silva, 2003; Weber, 2005). Aspects of family dynamics are considered in the qualification for adoption, such as marital stability and acceptance of the child by the nuclear and extended family (Campos \& Costa, 2003; Silva, 2003), as the acceptance of adoption by the extended family is considered important for the 448 adopting families (Campos \& Costa, 2003).
Adoption requires an act of will, a desire to be an adoptive parent (Azambuja, 2002; Maldonado, 1995). Legal adoption alone does not guarantee the mutual creation of affection between parents and children. In any situation involving parenting and the arrival of new members to the family, it is necessary to accept the child so that they will find their place and feel that they belong in the family (Campos \& Costa, 2003; Oliveira, 2007; Silva, 2003; Weber, 2005). Thus, it becomes important to work with the insecurity issues of adoption applicants; feelings of anxiety, and fear of the failure of the adoption; doubts concerning the fact that they are being judged by the adoption services and whether or not they will be selected as parents. The feeling of neglect and isolation when we are not informed about the progress of the process; the expectation regarding fraternal relationships, in the case of applicants having other children; as well as the illusions and idealizations of parenthood are also identified as important factors that should be taken into account in the adoption process (Campos \& Costa, 2003; Silva, 2003; Weber, 2005).

Once the adoption has been permitted, the stage of living becomes valid (Article 46 of the ECA), which is an adjustment period that aims to gradually construct bonds of affection between the adoptee, their parents and the other family members, in order to check the existence or otherwise of conflicts between the parties involved (Caíno, 2007; Granato, 2010; Silva, 2003). This stage must be monitored and evaluated by a multidisciplinary team of the Judiciary. Caíno (2007) says that it is through this stage of coexistence that the willingness to adopt and to be adopted is consolidated, because the interaction between the adopting family and the adoptee favors the creation and strengthening of the ties of affinity and affection.

It is clear, given the above, that an adoption process is permeated with psychological aspects on the part of everyone involved. Several feelings are present. For the children/adolescents, the fragility, vulnerability, rejection and fear of new abandonment are present. Conversely, feelings such as neediness, insecurity, anxiety and grief due to the desire to have had a biological child are part of the imaginary of those who want to become adoptive parents (Costa \& Campos, 2003; Oliveira, 2007; Weber, 2005). These aspects must 
be recognized and addressed in order to achieve a successful adoption.

\section{Main amendments of the National Adoption Law: Positive and negative aspects}

The National Adoption Law was enacted to regulate more details of the adoption procedure and to expedite the process of this protective measure. Among the main benefits provided, this Law stipulated a period of two years for the regularization of the situation of children/adolescents received, which had not been the case before, unless by proven need duly substantiated in a judicial decision (Medeiros, 2010). In this period, children/adolescents remain in foster care or institutional programs. The possibility of family reintegration or placement in a substitute family should be reassessed every six months, and a report should be sent to the Judiciary by the care institutions, stating the situation of each child/adolescent and their families (Rossato \& Lépore, 2009). Very few references to this reassessment can be found in the literature.

With respect to this period of institutionalization, which should be brief, it can be seen that often this is not the case in practice. This is partly because not all children/adolescents who are accepted can be adopted because they still have legal ties with their families of origin (Silva, 2004; Siqueira \& Dell'aglio 2006), and also because there is nowhere to put them after this period (Dias, 2009a). Sheltering institutions are often a form of social organization and provide close support to children/adolescents, with an important role in their development (Siqueira \& Dell'Aglio, 2006). Many parents leave their children in the shelter due to adverse conditions in the family and due to the care and socialization opportunities offered by the institutions (Siqueira \& Dell'Aglio, 2006), however, they retain family power over them, which makes the adoption process more difficult (Noal \& Neiva-Silva, 2007).

One issue that was unclear from the literature review conducted was whether the maximum term of two years for children/adolescents who were already taken in before the New Adoption Law commences anew with the enactment of the Law or whether the period is considered from the date of admission to the institute. The website of the Court of Appeals includes no statistics related to the number of years the children/ adolescents who are currently in institutions in Rio Grande do Sul have spent in care (Tribunal de Justiça do Rio Grande do Sul, 2011). However, according to the bibliographic research conducted, what can be seen is that the period of institutionalization is usually greater than two years (Silva, 2004; Siqueira \& Dell'Aglio, 2006).

Another change brought about by the New Law was the definition by the legislator of the concept of extended family and the reaffirmation of the need to maintain the emotional bonds and affinity of the child/ adolescent with their family of origin, such as grandparents, uncles, etc. (Granato, 2010; Medeiros, 2010). There were also changes in the provisions regarding placement in a substitute family, in order to avoid institutional care through custody, guardianship or adoption. However, the professionals responsible for this placement should observe the requirements included in the New Adoption Law, namely: the opinion of the child/adolescent, when possible, should be considered by an interdisciplinary team (respecting their development and degree of understanding for the consideration of their opinion); preference for placement of the child/adolescent in a family with which they have kinship and affinity or an affective relationship; preservation of the relationship between siblings, placing them in the same family; gradual preparation of the child/adolescent for their placement into a substitute family; in the case of indigenous children, their social and cultural identity must be respected, aiming to place them in families belonging to their community and their ethnicity (Figueiredo, 2010; Medeiros, 2010).

Other innovations were introduced, among them: the guarantee of the right to visits to the biological parents and their duty to provide child support to these children while under the care of other people (Dias, 2009a); the provision of psychological assistance to the pregnant mother who has an interest in giving up her child for adoption, with mandatory referral to the Judiciary; the prohibition of adoption by proxy; the setting of clear rules for the coexistence stage; and finally, the rigorous control of international adoption (Dias 2010; Figueiredo, 2010; Granato, 2010; Medeiros, 2010).

Concerning the personal rights of the children/ adolescents, the legislators, in the New Adoption Law, 
amended Article 48 of the ECA, which now includes the right of the adoptee to know their biological origin and to have unrestricted access, after 18 years of age, to the adoption process records. The latter had already been legally guaranteed.

Regarding care policy actions, programs have been included to prevent or reduce the time of removal of children/adolescents from family interaction, and campaigns to encourage the adoption of children older than three years and adolescents, children/adolescents with specific health needs or disabilities, of different races and groups of siblings (Rossato \& Lépore, 2009). New rules for the operation of sheltering institutions have been stipulated. A document was drafted and made binding, which will contain all the information about the institutionalized child/adolescent, called the "Sheltering Guide".

In order to seek a faster solution to the case, a set of rules was established for the care plan for the children/adolescents received, seeking their family reintegration. This care plan must contain the information and the goals of the care in relation to the children/ adolescents (Associação dos Magistrados Brasileiros, 2009). In addition, the plan must be prepared by the technical staff of the respective care program, and must take into account the views of the child and the testimony of his/her parents and guardians. As part of the process of family reintegration, if necessary, the family of origin of the child/adolescent should be included in the official programs of guidance, support and social promotion. Personal contact of the child/ adolescent with their family of origin should also be facilitated and stimulated.

One of the great innovations of the New Adoption Law was the compulsory creation of registers of future adopters and children/adolescents suitable for adoption, by judicial district, state and nationally. Such registers aim to meet the need to organize and unify updated information of children/adolescents suitable to be adopted in the country, as well as people and couples eligible to adopt, pursuant to the Statute of Children and Adolescents. Being statewide and national, it also aims to promote the integration of registers in the country, allowing cross-checking of children/

450 adolescents available for adoption with applicants to have them as children. There is also a register of individuals and couples living abroad who are able to adopt. This registry will only be consulted if there are no suitable applicants residing in the country listed in the national registry. Caíno (2007) estimates that, despite the bureaucracy involved in such records, they are of great value, as they aim to arrange the order of preference in the adoption of children/adolescents and provide greater agility in the processes. These registers facilitate the control and supervision of the processes. The placement of children/adolescents in substitute families illegally, in breach of the registry, is considered a crime (Granato, 2010). However, depending on the circumstances of the case, for example, the child/ adolescent is welcomed by a family, or if the child/ adolescent has their needs met by this family, the Court may determine that, even when in breach of the registry of adopters, the child/adolescent should not be removed from the household where they are illegally. In these cases, adoption is legalized due to it presenting real benefits for the child/adolescent.

Regarding the Cadastro Nacional de Adoção (CAN, National Adoption Registry), it is clear that the expectations were that it would be able to contribute to greater agility in the adoption progress (França, 2010). Rio Grande do Sul, in May 2011, had approximately 2,225 children/adolescents occupying places in shelters, and 768 children/adolescents suitable for adoption (Tribunal de Justiça do Rio Grande do Sul, 2011). This reaffirms that the majority of institutionalized children/adolescents are not suitable for adoption. The Adoption Records of the Court of Appeals found that, in the period from 01/01/2009 to 12/31/2009 (period prior to the enactment of the new Law until shortly after its enactment, which occurred in August/2009), there were 849 adoptions in the state, namely 233 (27.44\%) through the registry and 616 (72.56\%) directed adoptions. During the period from 01/01/2010 to 12/31/2010, after the Law was enacted, there were 96 adoptions in the state, namely 37 (38.54\%) through the registry and 59 (61.46\%) directed adoptions (Tribunal de Justiça do Rio Grande do Sul, 2011). Thus, it is clear that, in Rio Grande do Sul, the National Adoption Register has not shown that it is able to expedite the processes, making the National Adoption Law innocuous regarding this goal. 
It was also found, through the website of the Tribunal de Justiça do Rio Grande do Sul (2011), that there were 5,314 applicants for adoption. It is clear that in this state the expectation is different to the reality. Children/adolescents suitable for adoption are faced with the demands of adopters, who prefer newborn, white and healthy children (Capemisa, 2010; Noal \& Neiva-Silva, 2007), though, in most cases, the children are over eleven years of age (72.0\%). Furthermore, many of them have health problems, such as syndromes, deficiencies and AIDS (Tribunal de Justiça do Rio Grande do Sul, 2011). Children under two years of age represent only about $2.4 \%$ of those who are suitable for adoption. The preference of people from Rio Grande do Sul for adopting white newborns is confirmed by a survey conducted by the Court of Appeals of the State of Rio Grande do Sul in 2010. This survey indicated that 55.21\% of adoptions were of children under two years of age and $51.04 \%$ of white children (Tribunal de Justiça do Rio Grande do Sul, 2011).

With regard to these preferences, another positive aspect created by the New Adoption Law concerns campaigns of guidance and encouragement to accept children over three years of age and adolescents who have special needs or a serious illness. There was also encouragement of the adoption of black children/adolescents and sibling groups, as it is still a challenge to find families for these children. It should be noted that this profile presented in Rio Grande do sul has been changing. The current data concerning the diversification of the profile of adoptions in the state of Rio Grande do Sul is encouraging. The proportion of black or brown adoptees has increased by almost a third over the previous five years (Instituto Amigos de Lucas, 2010).

Regarding the negative aspects, the New Adoption Law is considered too bureaucratic (Dias, 2009a). An example of this concerns the rules for a mother who wants to give up her child for adoption. Consent must be given in a hearing by a Judge, with the presence of the Prosecution Office, after exhausting efforts to keep the child with the family of origin. Another example is the eligibility for adoption, which became a major proceeding, with complaint and follow up through a series of documents (Dias, 2009a, 2010).

Another aspect considered to be negative regards adoption by homosexual couples. The new law has lost a great chance to be innovative by not clearly allowing in its text the possibility of same-sex couples becoming adoptive parents. However, it can be seen that in some case laws surpass this understanding and allow same-sex couples to adopt (Dias, 2009a; Rossato \& Lépore, 2009).

Another aspect refers to the fact that most children/adolescents who are currently in sheltering institutions have families and are not suitable for adoption. As mentioned earlier, in 2011, Rio Grande do Sul had only 768 children suitable for adoption of the 2,225 in institutions (Tribunal de Justiça do Rio Grande do Sul, 2011). This reality makes the adoption process difficult for applicants (França, 2010). One of the main reasons for the delay in adoption is that the Court first needs to attempt a reconciliation of the child/adolescent with their biological parents. No matter how poor the conditions of the parents, including their ability to care for their children, the Law prioritizes keeping the children/adolescents with their family of origin. By prioritizing family life, the new Law transformed adoption in an exceptional measure and ultimately created more barriers for its performance, instead of making the process faster (Dias, 2009a). While agreeing that the sheltering institutions should be guided by the principle of preservation of family ties and the promotion of family reintegration, and that placement in a substitute family should be sought only when it is not possible to maintain the child/adolescent in their natural or extended family, the question is to what extent should this reintegration be "forced"?

\section{Final Considerations}

Based on this study, it can be seen that the New Adoption Law is a powerful tool for change in the concept and practice in both institutional sheltering entities and in all those involved in the adoption process. It must be understood that adoption is permeated with a significant complexity, especially as it involves individuals in the process of biopsychosocial development. Therefore, it is imperative for healthcare professionals to perform a systematic reflection of their social, professional and personal practices, contemplating paradigm changes arising from the present moment. 
This article reveals that there are still many shortcomings in the implementation of measures to protect children/adolescents in situations of adoption. It should be noted that with this theoretical research alone and based on statistical data of the state of Rio Grande do Sul it was not possible to identify whether the professionals working in the sheltering institutions really understand the New Law and know how to use it in favor of the institutions. Future work investigating the perception of professionals regarding the changes that occurred after the enactment of this law is therefore suggested.

One cannot fail to recognize that legislators are faced with difficult issues related to children and youths. When taking into account the psychological damage that comes from institutionalization, legislators addressed the monitoring of the situation of children/adolescents and their families and sought to limit their time spent in the sheltering institutions (to two years).

Despite all these benefits, adoption, following thenewLaw, has becomemoreformalistic and bureaucratic, and the Law failed to provide speedier adoption processes, as shown by the literature studied and the statistics regarding adoption in the state of Rio Grande do Sul. Based on the investigated sources, it can be said that it is more than an "Adoption Law", it is a true "Family Coexistence Law". At its core is the quest for the maintenance of children/adolescents with their biological family and the preservation of family ties. As a result, there has been no solution to the situation for the majority of institutionalized children/adolescents. It should be highlighted that the statistical research presented did not include national data and was restricted only to the state of Rio Grande do Sul. The notes, made in this study, regarding the negative and positive aspects involved in the main changes introduced by the New Adoption Law, aim to contribute towards its improvement. Thus, it is suggested that future research should be conducted in other states, in order to examine the adoption situations and to implement the National Adoption Law throughout Brazil.

\section{References}

Associação dos Magistrados Brasileiros. (2009). Novas regras 452 para adoção: guia comentado. Recuperado em junho 9,
2010, disponível em <http://www.amb.com.br/docs/ noticias/2009/adocao_comentado.pdf>.

Azambuja, M. R. F. (2002). A adoção sob a perspectiva da doutrina da proteção integral. In D. Zimerman \& A. C. M. Coltro (Orgs.), Aspectos psicológicos na prática jurídica (pp.303-317). Campinas: Millennium.

Brasil. Casa Civil. (1990, 16 de julho). Lei no 8.069, de 13 de julho de 1990. Estatuto da criança e do adolescente. Diário Oficial da União, Seção 1. Recuperado em novembro 8, 2010, disponível em <http://www.planalto.gov.br/ ccivil_03/Leis/L8069.htm>.

Brasil. Casa Civil. (2002, 11 de janeiro). Lei no 10.406, de 10 de janeiro de 2002. Institui o Código Civil. Diário Oficial da União, Seção 1. Recuperado em novembro 8, 2010, disponível em <http://www.planalto.gov.br/ccivil_03/leis/ 2002/l10406.htm>.

Brasil. Casa Civil. (2009, 4 de agosto). Lei no 12.010, de 3 de agosto de 2009. Dispõe sobre adoção. Altera as Leis $n^{\circ}$ 8.069, de 13 de julho de 1990 - Estatuto da Criança e do Adolescente, 8.560, de 29 de dezembro de 1992; revoga dispositivos da Lei no 10.406, de 10 de janeiro de 2002 Código Civil, e da Consolidação das Leis do Trabalho CLT, aprovada pelo Decreto-Lei n 5.452, de 10 de maio de 1943; e dá outras providências. Diário Oficial da União. Seção 1. Recuperado em novembro 8, 2010, disponível em <http://www.planalto.gov.br/ccivil/_Ato2007-2010/ 2009/Lei/L12010.htm>.

Caíno, D. C. B. (2007). Adoção intuito personae. (Monografia de Especialização não-publicada). Programa de Pós-Graduação em Interesses Difusos e Coletivos, Fundação Escola Superior do Ministério Público do Rio Grande do Sul. Porto Alegre.

Campos, N. M. V., \& Costa, L. F. (2003). A avaliação psicossocial no contexto da adoção: vivências das famílias adotantes. Psicologia: Teoria e Pesquisa, 19(3), 221-230.

Campos, N. M. V., \& Costa, L. F. (2004). A subjetividade presente no estudo psicossocial da adoção. Psicologia, Reflexão e Crítica, 17(1), 95-104.

Capemisa Social. (2010). Adoção: 37\% dos casais só querem crianças brancas. Recuperado em fevereiro 16, 2011, disponível em <http://www.capemisasocial.org.br/cape misasocial/blog/Lists/Postagens/Post.aspx?|D=50>.

Dias, M. B. (2009a). O lar que não chegou. Recuperado em maio 20,2010, disponível em <http://www.ibdfam.org.br/ ?artigos\&artigo=527>.

Dias, M. B. (2009b). Manual de direito das famílias (5a ed.). São Paulo: Revista dos Tribunais.

Dias, M. B. (2010). O lar que não chegou. Revista IOB: Direito de Família, 11(57), 12-15.

Figueiredo, L. C. B. (2010). Comentários à nova lei da adoção. Curitiba: Juruá.

Filhos do Coração. (2008). Porque o processo de adoção é demorado? Rio de Janeiro: Rede Globo. Recuperado em dezembro 5, 2010, disponível em <http://video.globo. com/Videos/Player/Noticias/0, GIM788937-7823-FILHOS $+\mathrm{DO}+\mathrm{CORACAO}+\mathrm{PORQUE}+\mathrm{O}+\mathrm{PROCESSO}+\mathrm{DE}+\mathrm{ADOCAO}$ $+\mathrm{E}+\mathrm{DEMORADO}, 00 \cdot \mathrm{html}$. 
França, L. (2010). Adoção. Recuperado em maio 5, 2010, disponível em <http://veja.abril.com.br/especiais_online/ adocao/abre.html $>$.

Granato, E. F. R. (2010). Adoção, doutrina e prática: com comentários à nova lei da adoção, Lei 12.010/09. Curitiba: Juruá.

Instituto Amigos de Lucas. (2010). Em busca de um lar: perfil de adoções se diversifica no estado. Recuperado em agosto 10, 2010, disponível em <http://www.amigosdelucas. org.br/blog/?p=1138>

Maldonado, M. T. (1995). Os caminhos do coração: pais e filhos adotivos. São Paulo: Saraiva.

Medeiros, A. S. C. (2010). Breves considerações sobre a nova lei da adoção. Revista IOB de Direito de Família, 11(57), 7-11.

Noal, J., \& Neiva-Silva, L. (2007). Adoção, adoção tardia e apadrinhamento afetivo: intervenções em relação a crianças e adolescentes. In C. S. Hutz (Org.), Prevenção eintervenção em situações de risco evulnerabilidade (pp.7-48). São Paulo: Casa do Psicólogo.

Oliveira, D. S. (2007). Os aspectos emocionais envolvidos no processo de adoção. In Fundação Escola Superior do Ministério Público. Revista da Faculdade de Direito da FMP (Vol. 1, pp.166-179).

Paiva, L. D. (2004). Adoção: significados e possibilidades. São Paulo: Casa do Psicólogo.
Rossato, L. A., \& Lépore, P. E. (2009). Comentários à leinacional da adoção: Lei 12.010, de 3 de agosto de 2009. São Paulo: Revista dos Tribunais.

Silva, C. C. H. (2006). A medida de abrigo como alternativa: um estudo no abrigo de Gravataí - RS (Monografia de Especialização não-publicada). Programa de Pós-Graduação em Direito da Criança e Adolescente, Fundação Escola Superior do Ministério Público de Porto Alegre.

Silva, D. M. (2003). Psicologia jurídica no processo civil brasileiro. São Paulo: Casa do Psicólogo.

Silva, E. R. A. (2004). O perfil da criança e do adolescente nos abrigos pesquisados. In E. R. A. Silva (Org), O direito à convivência familiar e comunitária: os abrigos para crianças e adolescentes no Brasil (pp.44-69). Brasília: IPEA.

Siqueira, A. C., \& Dell'Aglio, D. D. (2006). O impacto da institucionalização na infância e na adolescência: uma revisão de literatura. Psicologia \& Sociedade, 18(1), 71-80.

Tribunal de Justiça do Rio Grande do Sul. (2011). Estatísticas. Recuperado em maio 12, 2011, disponível em http:// jij.tj.rs.gov.br/jij_site/jii_site.wwv_main.main?p_cornerid $=856 \& p \_$currcornerid $=1 \& p \_$language $=$ptb\&p_edit $=0 \&$ p_full=1\&p_cornertype $=$ item\&p_iscornerlink $=1$.

Weber, L. N. D. (2005). O psicólogo e as práticas de adoção. Rio de Janeiro: Psicologia Jurídica no Brasil.

Received on: 6/10/2011

Final version on: 3/4/2012

Approved on: 24/4/2012 